\title{
Statistical optimization of extracellular tannase production by Streptomyces sp. AT 13 using response surface methodology and Plackett-Burmen design
}

\author{
Archana D. Tripathi* and Lakshmi B. \\ Department of Biotechnology, Kadi Sarva Vishwavidyalaya, Gandhinagar, Pin-382028, Gujarat, India
}

\begin{abstract}
Tannase has many important applications in animal feed, chemical, food, and pharmaceutical industries. In the present study, optimization of tannase production by Streptomyces sp. AT13 was carried out using statistical experimental designs. Initially, a Plackett-Burmen design (PBD) was employed to screen the preferable nutriments (carbon and nitrogen sources of the medium) to produce tannase. The result showed that only tannic acid was found to be significant for the production of tannase by Streptomyces sp. AT 13. The significant factor was further optimized by using Box-Behnken design under response surface methodology (RSM). From among 6 fermentative variables that were studied, 5 significant variables were picked up by PBD. Among 5 variables from PBD, 3 were further optimized by Box-Behnken design. The parameters studied through RSM were 1\% Tannic Acid, $0.5 \%$ $\mathrm{KCl}$ and $0.1 \% \mathrm{KH}_{2} \mathrm{PO}_{4}$. Under optimized conditions tannase activity was $18.12 \mathrm{U} / \mathrm{ml} / \mathrm{min}$. This activity was almost three times higher as compared to the amount obtained by 'one-at-a-time' approach. (5.19 U/ml/min)
\end{abstract}

\section{INTRODUCTION}

Tannins are polyphenolic compounds with molecular weights ranging from 500 to 3000 daltons which occur widely ina variety of plants including monocots, dicots and ferns (Bate-Smith and Swain 1962; Mcleod 1974; Haslam 1989). They are the fourth most abundant plant constituents after cellulose, hemicellulose and lignin.
Based on their structure and properties, tannins are distributed into two major groups - hydrolysable and condensed tannins. Hydrolysable tannins are composed of esters of gallic acid (gallotannins) or ellagic acid (ellagitannins) with a sugar core, which is usually glucose, and are readily hydrolysed by acids and enzymes into monomeric products. Hydrolysable tannins are notably absent in monocots. Commercially, hydrolysable tannins

\section{ARTICLE INFORMATION:}

Corresponding Authors: archana315@gmail.com, lakjayan@gmail.com

Received $19^{\text {th }}$ Sep, 2018

Accepted after revision $18^{\text {st }}$ Dec, 2018

BBRC Print ISSN: 0974-6455

Online ISSN: 2321-4007 CODEN: USA BBRCBA Thomson Reuters ISI ESC / Clarivate Analytics USA

Mono of Clarivate Analytics and Crossref Indexed Journal Mono of $C R$

NAAS Journal Score 2018: 4.31 SJIF 2017: 4.196

- A Society of Science and Nature Publication, Bhopal India 2018. All rights reserved.

Online Contents Available at: http//www.bbrc.in/

DOI: $10.21786 / \mathrm{bbrc} / 11.4 / 21$ 
are extracted from Chinese gall (Rhus semialata), Sumac (R. coriara), Turkish gall (Quercus infectoria), Tara (Caesalpina spinosa), Myrobalan nuts (Terminalia chebula) and chestnuts (Castania sativa) (Bhat et al., 1998).

Tannase (tannin acyl hydrolase) catalyses the hydrolysis of ester and depside bonds of hydrolysable tannins to produce glucose and gallic acid (Barthomeuf et al.,1994). Hydrolysis of tannic acid by tannase results in the liberation of glucose, gallic acid and various galloyl esters of glucose (Van de Lagemaat and Pyle, 2006). This enzyme finds widespread applications in food processing, brewing, pharmaceuticals, medicine, textiles, detergents and tea industry (Lekha and Lonsane, 1997). A combination of trimethoprim and sulphonamide is effective against many antibiotic resistant species of bacteria. More than 8000 tonnes per annum of gallic acid is manufactured out of which, almost 70\% is used in production of trimethoprim (Beena, 2010).

The use of a sequential experimental design strategy is a useful tool for process optimization. Response surface methodology (RSM) provides important information regarding the optimum level of each variable along with its interactions with other variables and their effects on product yield. It reduces the number of experiments without neglecting the interactions among the parameters. This multivariate approach also improves statistical interpretation possibilities and evaluates the relative significance of several contributing factors even in the presence of complex interactions (Dilipkumar et al., 2011). RSM is widely used for multivariable optimization studies in several biotechnological processes such as the optimization of media, process conditions etc. (Mannan et al., 2007; Pan et al., 2008). Statistical optimization allows the interaction amid possible influencing parameters to be evaluated with a limited number of experiments (Rodriguez et al., 2008). Statistical designs such as Plackett-Burman and Response surface methodology are common in practice for testing multiple factors and interactions that can be quantified in an error-free and robust manner (Mohan, 2014).

In order to fully exploit the prospective of this enzyme for various applications, it is imperative to investigate the possibility of enhancing its production by using more efficient production strategies (Rana and Bhat, 2005). Hence in this study the process parameters were optimized for maximum enzyme production adopting Plackett-Burman (PB) and Response Surface Methodology (RSM) with Box Behnken design. The statistical software package DesignExpert ${ }^{\circledR} 7.0$ (Stat Ease Inc., Minneapolis, and USA) was used.

\section{MATERIALS AND METHODS}

Tannic Acid was purchased from Sigma Aldrich, USA. All other chemicals and reagents were used of analytical grade and purchased from Hi-Media, India. Sterptomyces sp. AT 13 used for the present study was screened and isolated from Tannery Effluent at G.I.D.C Naroda, Ahmedabad and the organism was maintained on tannic acid agar (TAA) medium. Tannase production by Sterptomyces sp. AT 13 was carried out using tannase production medium containing $\mathrm{NaNO}_{3} 0.6 \% \mathrm{w} / \mathrm{v}, \mathrm{KCl} 0.5$ $\% \mathrm{w} / \mathrm{v}, \mathrm{MgSO}_{4} 0.05 \% \mathrm{w} / \mathrm{v}, \mathrm{K}_{2} \mathrm{HPO}_{4} 0.05 \% \mathrm{w} / \mathrm{v}, \mathrm{KH}_{2} \mathrm{PO}_{4}$ $0.05 \% \mathrm{w} / \mathrm{v}$ and $1 \%(\mathrm{w} / \mathrm{v})$ filtered sterilized tannic acid (designated as TA broth). The broth was assayed for tannase activity.

\section{TANNASE ASSAY}

The tannase activity was estimated by modified spectrophotometric method of Sharma et al., 2000. Tannic Acid was used as substrate. The basic principle of this assay is based on the formation of chromogen between gallic acid (released by the action of tannase on tannic acid) and rhodanine (2-thio-4-ketothiazolidine). A standard curve was prepared using gallic acid.Crude enzyme was used for the assay. All the tests were performed in triplicates. One unit of tannase activity is defined as the amount of enzyme required to liberate $1 \mu \mathrm{M}$ of gallic acid /min under defined conditions. Enzyme activity was expressed as $\mathrm{U} / \mathrm{ml} / \mathrm{min}$.

\section{Plackett-Burman design}

Plackett-Burman design, an efficient technique for medium component selection (Plackett-Burman, 1946) was employed to establish the factors that significantly enhance the tannase production. Five independent variables (Table 1) were analysed in 12 experimental runs (Table 2) for the production of tannase. Triplicates were maintained for each experimental set up. The response of these factors for the production of tannase was measured by Spectrophotometer method as proposed by Sharma et al., (2000). The low level (-1) and the high level $(+1)$ of each factors are demonstrated in Table 2 . The statistical software design expert 6.0 was used for analysing the experiment. Total 5 independent variables

\begin{tabular}{|c|c|c|c|}
\hline $\begin{array}{l}\text { Variable } \\
\text { codes }\end{array}$ & Variables & $\begin{array}{c}\text { Low } \\
\text { level }(-1)\end{array}$ & $\begin{array}{c}\text { High } \\
\text { level }(+1)\end{array}$ \\
\hline A & Tannic Acid & -1 & +1 \\
\hline B & $\mathrm{KCl}$ & -1 & +1 \\
\hline C & $\mathrm{NaNO}_{3}$ & -1 & +1 \\
\hline D & $\mathrm{KH}_{2} \mathrm{PO}_{4}$ & -1 & +1 \\
\hline E & $\mathrm{K}_{2} \mathrm{HPO}_{4}$ & -1 & +1 \\
\hline
\end{tabular}


Table 2. Plackett Burman design matrix for the screening of variables

\begin{tabular}{|l|c|c|c|c|c|c|c|c|c|c|c|c|}
\hline & $\mathrm{F} 1$ & $\mathrm{~F} 2$ & $\mathrm{~F} 3$ & $\mathrm{~F} 4$ & $\mathrm{~F} 5$ & $\mathrm{~F} 6$ & $\mathrm{~F} 7$ & $\mathrm{~F} 8$ & $\mathrm{~F} 9$ & $\mathrm{~F} 10$ & $\mathrm{~F} 11$ & \\
\hline Run & $\begin{array}{c}\text { A:Tannic } \\
\text { Acid }\end{array}$ & $\mathrm{B}: \mathrm{KCl}$ & $\mathrm{C}: \mathrm{NaNO}_{3}$ & $\mathrm{D}: \mathrm{KH}_{2} \mathrm{PO}_{4}$ & $\mathrm{E}_{2} \mathrm{HPO}_{4}$ & $\mathrm{~F}: \mathrm{F}$ & $\mathrm{G}: \mathrm{G}$ & $\mathrm{H}: \mathrm{H}$ & $\mathrm{J}: \mathrm{J}$ & $\mathrm{K}: \mathrm{K}$ & $\mathrm{L}: \mathrm{L}$ & $\mathrm{R}$ 1 \\
\hline 1 & -1.00 & 1.00 & 1.00 & 1.00 & -1.00 & -1.00 & -1.00 & 1.00 & -1.00 & 1.00 & 1.00 & 1.62 \\
\hline 2 & 1.00 & 1.00 & 1.00 & -1.00 & -1.00 & -1.00 & 1.00 & -1.00 & 1.00 & 1.00 & -1.00 & 12.99 \\
\hline 3 & 1.00 & -1.00 & 1.00 & 1.00 & -1.00 & 1.00 & 1.00 & 1.00 & -1.00 & -1.00 & -1.00 & 7.17 \\
\hline 4 & -1.00 & -1.00 & -1.00 & -1.00 & -1.00 & -1.00 & -1.00 & -1.00 & -1.00 & -1.00 & -1.00 & 10.12 \\
\hline 5 & 1.00 & 1.00 & -1.00 & 1.00 & 1.00 & 1.00 & -1.00 & -1.00 & -1.00 & 1.00 & -1.00 & 16.53 \\
\hline 6 & -1.00 & 1.00 & -1.00 & 1.00 & 1.00 & -1.00 & 1.00 & 1.00 & 1.00 & -1.00 & -1.00 & 5.61 \\
\hline 7 & -1.00 & -1.00 & -1.00 & 1.00 & -1.00 & 1.00 & 1.00 & -1.00 & 1.00 & 1.00 & 1.00 & 5.91 \\
\hline 8 & 1.00 & -1.00 & 1.00 & 1.00 & 1.00 & -1.00 & -1.00 & -1.00 & 1.00 & -1.00 & 1.00 & 16.2 \\
\hline 9 & -1.00 & -1.00 & 1.00 & -1.00 & 1.00 & 1.00 & -1.00 & 1.00 & 1.00 & 1.00 & -1.00 & 2.58 \\
\hline 10 & -1.00 & 1.00 & 1.00 & -1.00 & 1.00 & 1.00 & 1.00 & -1.00 & -1.00 & -1.00 & 1.00 & 0.3 \\
\hline 11 & 1.00 & 1.00 & -1.00 & -1.00 & -1.00 & 1.00 & -1.00 & 1.00 & 1.00 & -1.00 & 1.00 & 15.75 \\
\hline 12 & 1.00 & -1.00 & -1.00 & -1.00 & 1.00 & -1.00 & 1.00 & 1.00 & -1.00 & 1.00 & 1.00 & 0.36 \\
\hline
\end{tabular}

along with 5 dummy variables generated by the software. All the experiments were done in triplicate and the average of lipase production was taken as response. The obtained results are matched with the polynomial equation 1 in significant order 1 :

$$
\mathrm{Y}=\beta 0+\Sigma \beta \mathrm{iXi}(\mathrm{i}=1,2,3 .
$$

Where $\mathrm{Y}$ is the response (Enzyme activity), $\beta 0$ is model intercept, $\beta \mathrm{i}$ is linear coefficient, $\mathrm{Xi}$ is level of the independent variables. The model was statistically analyzed and the overall significance of the model was evaluated by ANOVA (Analysis of variance) involving Fischer's test (F test). P (probability) values and determination of coefficient obtained determines regression model's goodness of fit.

\section{Box-Behenken Design}

After optimizing the various nutritional variables by $\mathrm{PBD}$, the 3 most significant variables (Tannic Acid, $\mathrm{KCl}$ and $\mathrm{KH}_{2} \mathrm{PO}_{4}$ ) were further chosen for response surface methodology using Box-Behnken design. Design-Expert ${ }^{\circledR}$ statistical software was used to analyze the experimental design. A Box-Behnken design with a set of 12 experiments was generated (Table 4). Each variable was stud-

\begin{tabular}{|c|c|c|c|c|c|c|}
\hline \multicolumn{7}{|c|}{ Analysis of variance table [Partial sum of squares - Type III] } \\
\hline & Sum of & & Mean & $\mathrm{F}$ & p-value & \\
\hline Source & Squares & df & Square & Value & Prob $>F$ & \\
\hline Model & 427.76 & 10 & 42.78 & 285.87 & 0.0460 & significant \\
\hline A-TANNIC ACID & 153.08 & 1 & 153.08 & 1023.04 & 0.0199 & \\
\hline $\mathrm{B}-\mathrm{KCl}$ & 9.12 & 1 & 9.12 & 60.93 & 0.0811 & \\
\hline $\mathrm{C}-\mathrm{NaNO}_{3}$ & 15.01 & 1 & 15.01 & 100.30 & 0.0634 & \\
\hline $\mathrm{D}-\mathrm{KH}_{2} \mathrm{PO}_{4}$ & 9.97 & 1 & 9.97 & 66.65 & 0.0776 & \\
\hline $\mathrm{E}-\mathrm{K}_{2} \mathrm{HPO}_{4}$ & 11.96 & 1 & 11.96 & 79.93 & 0.0709 & \\
\hline G-G & 77.32 & 1 & 77.32 & 516.71 & 0.0280 & \\
\hline $\mathrm{H}-\mathrm{H}$ & 69.89 & 1 & 69.89 & 467.08 & 0.0294 & \\
\hline J-J & 43.85 & 1 & 43.85 & 293.07 & 0.0371 & \\
\hline $\mathrm{K}-\mathrm{K}$ & 19.15 & 1 & 19.15 & 127.99 & 0.0561 & \\
\hline $\mathrm{L}-\mathrm{L}$ & 18.40 & 1 & 18.40 & 122.98 & 0.0573 & \\
\hline Residual & 0.15 & 1 & 0.15 & & & \\
\hline Cor Total & 427.91 & 11 & & & & \\
\hline
\end{tabular}




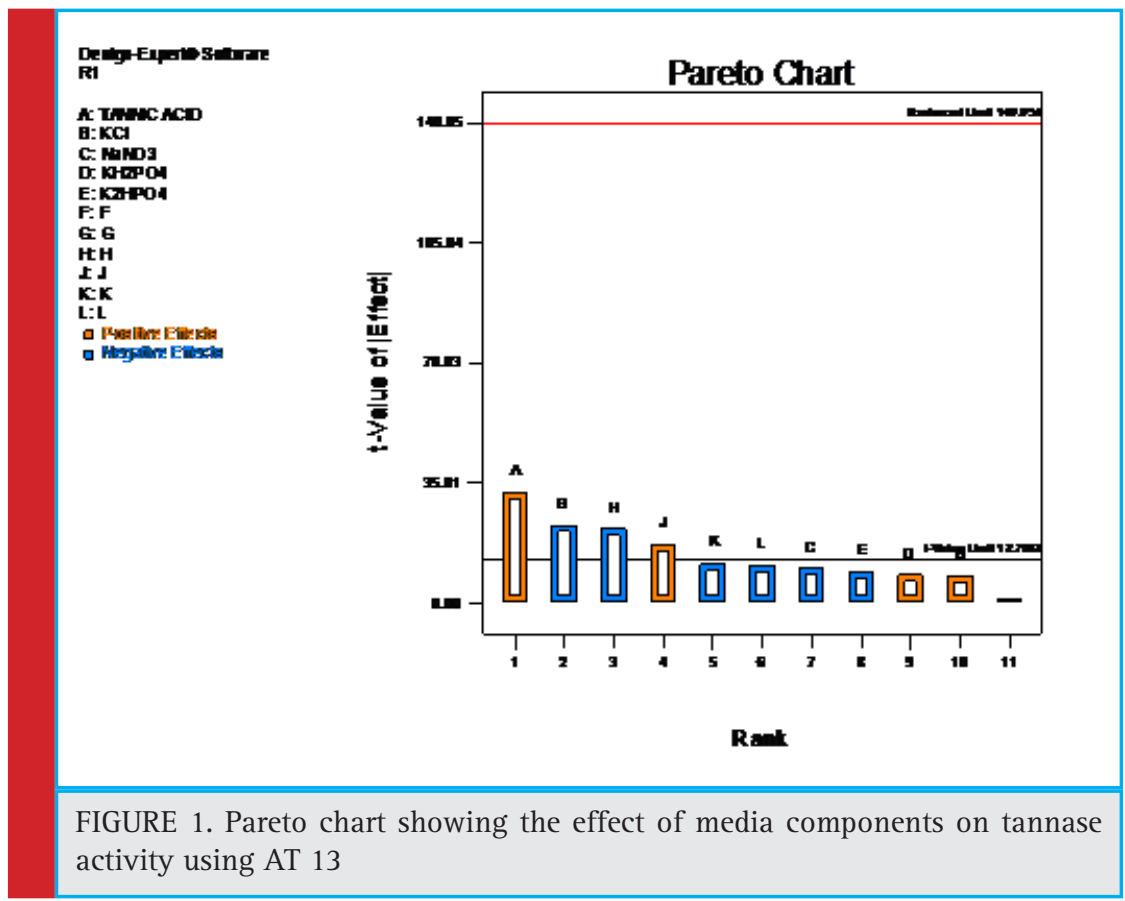

ied at three levels, $+1,0,-1$ where " 0 " is the central coded value, "+1" high value and "- 1 " low value. The fermentation was carried out in $250 \mathrm{ml}$ flasks containing $100 \mathrm{ml}$ of the production medium. All experiments were done in triplicate and tannase production obtained was taken as the response.

The obtained results are matched with the polynomial equation 2 in significant order

$$
\mathrm{Y}=\beta 0+\Sigma \beta \mathrm{iXi}+\Sigma \beta \mathrm{iiXi} 2+\Sigma \beta \mathrm{ijXiXj}
$$

where $\mathrm{Y}$ is the predicted response, $\beta 0$ is the intercept term, $\mathrm{Xi}$ and $\mathrm{Xj}$ are the input variables, $\beta \mathrm{i}$ the linear

\begin{tabular}{|c|c|c|c|c|}
\hline & Tannic Acid & $\mathrm{KCl}$ & $\mathrm{KH}_{2} \mathrm{PO}_{4}$ & E.A \\
\hline Run & A:A & B:B & $\mathrm{C}: \mathrm{C}$ & R1 \\
\hline 1 & -1.00 & 1.00 & 0.00 & 12.99 \\
\hline 2 & -1.00 & 0.00 & -1.00 & 14.61 \\
\hline 3 & 0.00 & 1.00 & 1.00 & 17.34 \\
\hline 4 & 0.00 & -1.00 & 1.00 & 12.33 \\
\hline 5 & 0.00 & 1.00 & -1.00 & 11.52 \\
\hline 6 & 1.00 & 0.00 & 1.00 & 9.27 \\
\hline 7 & 1.00 & 0.00 & -1.00 & 10.71 \\
\hline 8 & 1.00 & 1.00 & 0.00 & 2.61 \\
\hline 9 & -1.00 & -1.00 & 0.00 & 9.66 \\
\hline 10 & 1.00 & -1.00 & 0.00 & 6.57 \\
\hline 11 & 0.00 & -1.00 & -1.00 & 17.79 \\
\hline 12 & -1.00 & 0.00 & 1.00 & 18.12 \\
\hline
\end{tabular}

coefficients, $\beta \mathrm{ii}$ the squared coefficients and $\beta \mathrm{ij}$ the interaction coefficients. The model was statistically analyzed and the overall significance of the model was evaluated by ANOVA (Analysis of variance) involving Fischer's test ( $F$ test). $P$ (probability) values and coefficient of determination obtained determines regression model's goodness of fit. The optimum values of each of the 3 significant variables were determined by solving regression equation.

The interactive effects of the variables on tannase production were studied by analyzing the $3 \mathrm{D}$ and counter plots which depicted the interactions graphically.

Validation of the model: The statistical model was again tested by carrying out the fermentation under the optimum conditions that were obtained through the BoxBehnken design.

\section{RESULTS AND DISCUSSION}

\section{SCREENING OF VARIABLES BY PBD}

Iimportant fermentative parameters can be effectively and quickly picked up by applying PBD. The use of statistical tools not only saves time by simultaneously optimizing several process variables with few experimental runs but also reduces the cost of fermentation. A total of 5 important variables Viz., tannic acid, $\mathrm{KCl}, \mathrm{NaNO}_{3}$ $\mathrm{KH}_{2} \mathrm{PO}_{4}$ and $\mathrm{K}_{2} \mathrm{HPO}_{4}$ which were selected for statistical optimization using PBD (Table 1).

Experiments were carried out based on Plackett-Burman design and the results obtained are given in Table 2. 


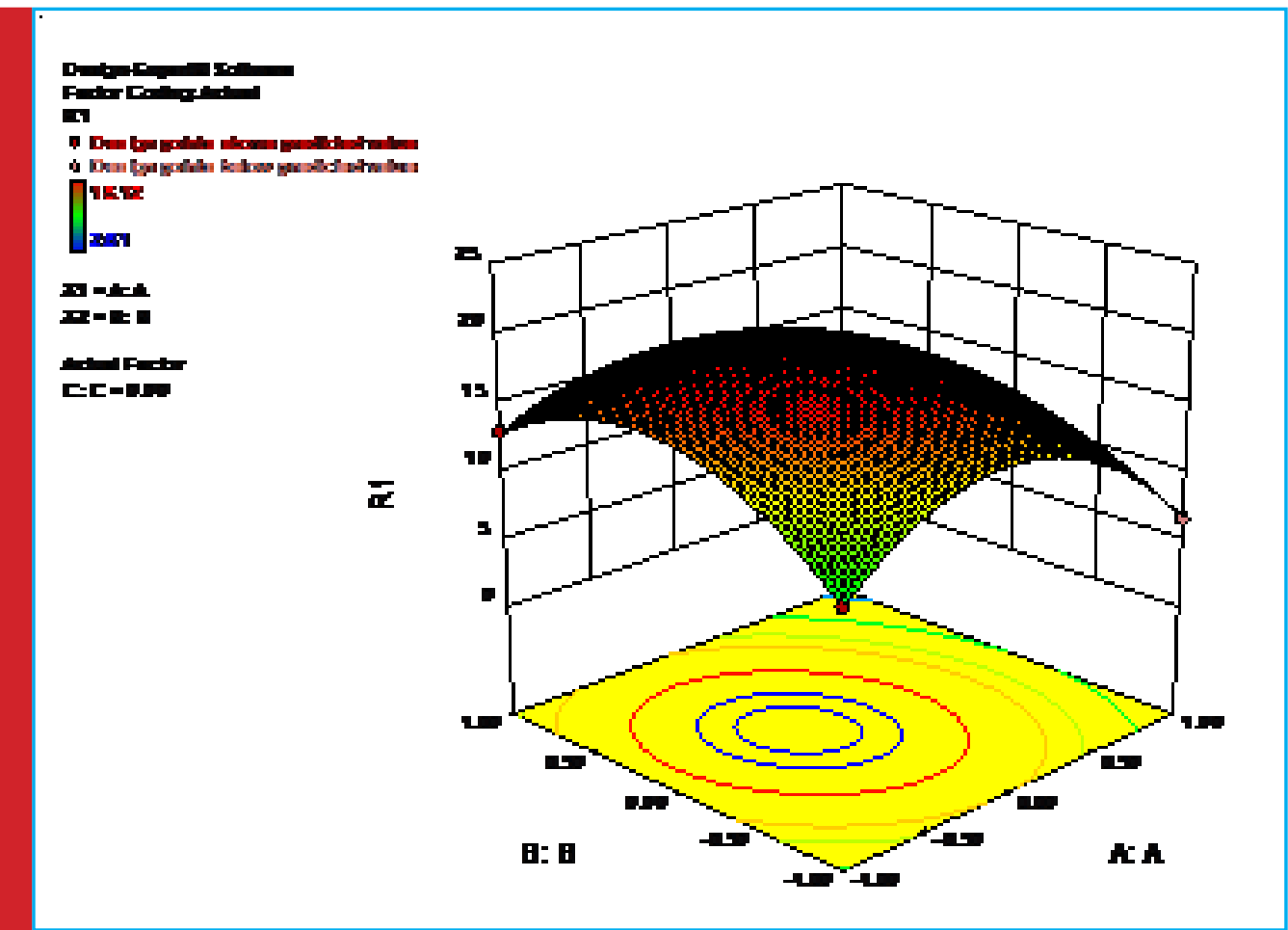

FIGURE 2a. Response surface plot of tannase production by AT 13 showing interaction between tannic acid and $\mathrm{KCl}$

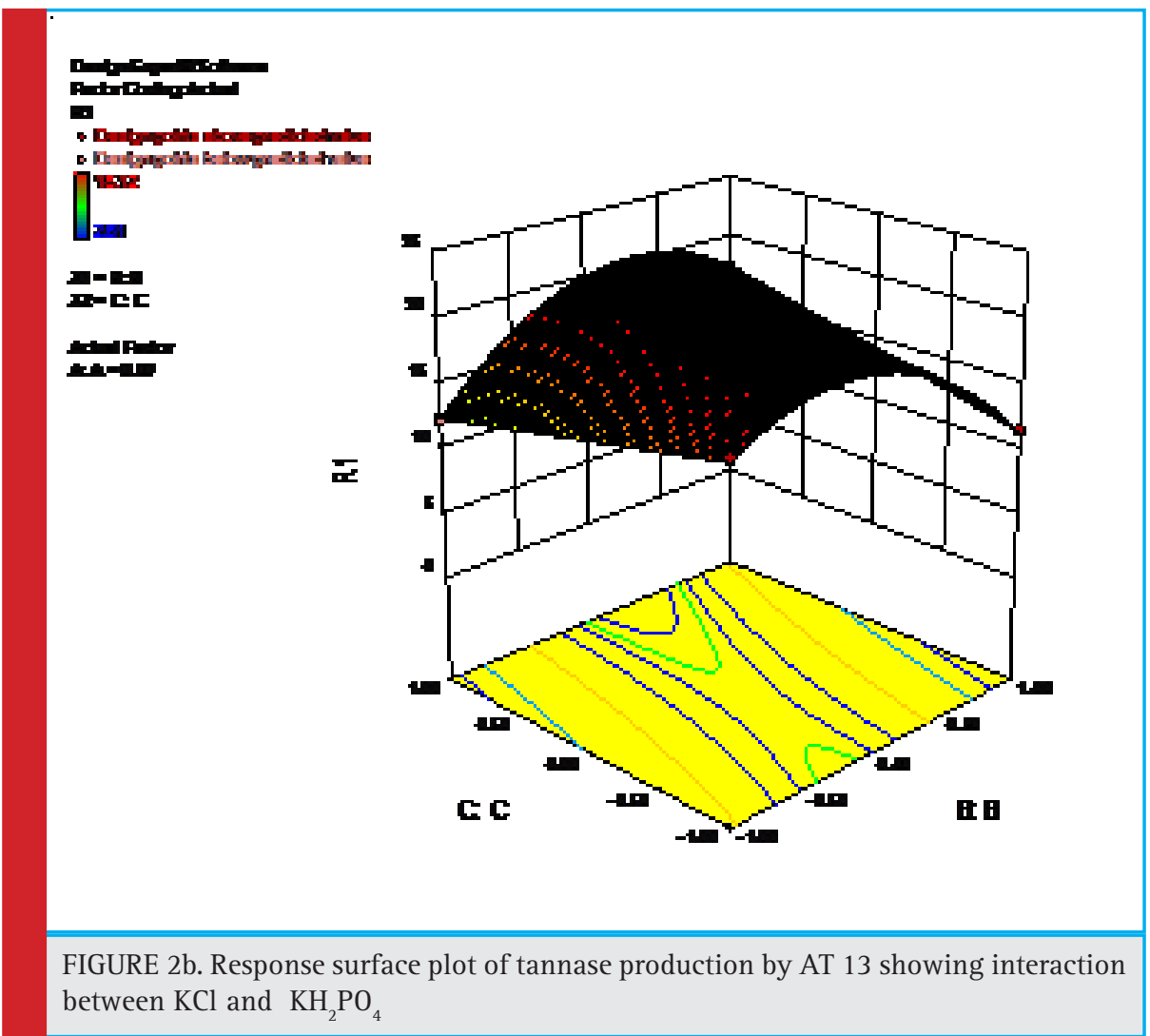




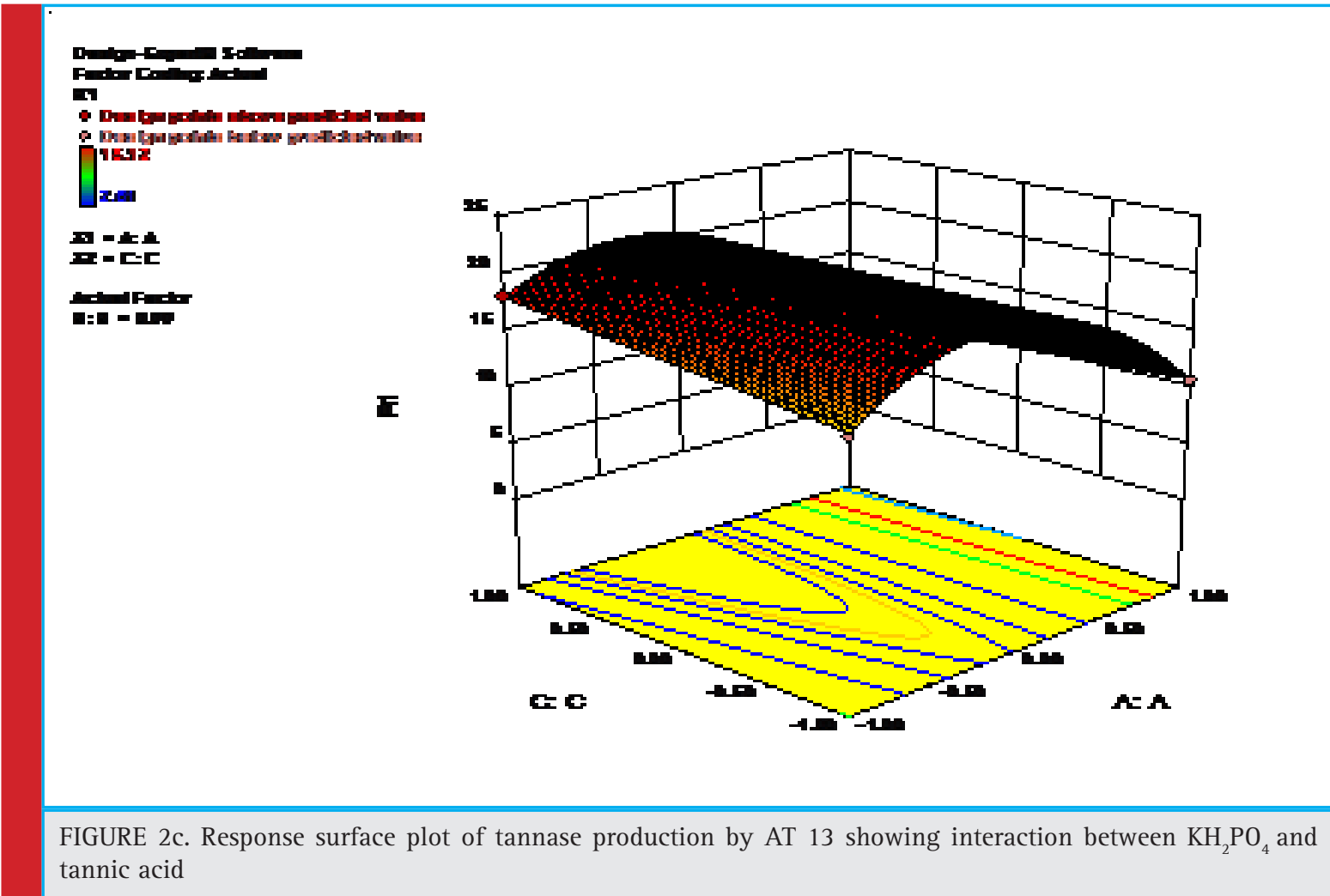

From the table, it was observed that the variation in tannase activity was $0.3-16.53 \mathrm{U} / \mathrm{ml} / \mathrm{min}$. From the Pareto chart (Fig. 1), only tannic acid was found to be significant for the production of tannase by AT 13 .

Figure 1 show the Pareto chart of effects of variables on tannase production which helps in. identify- ing important factors that are mainly responsible for enzyme production. From the chart it was evident that the most important contributing factor for tannase production was tannic acid only.

The ANOVA results are given in Table 3. The p-value of ANOVA table serves as a tool for checking the sig-

\begin{tabular}{|c|c|c|c|c|c|c|}
\hline \multicolumn{7}{|c|}{ Analysis of variance table [Partial sum of squares - Type III] } \\
\hline & Sum of & & Mean & $\mathrm{F}$ & p-value & \\
\hline Source & Squares & df & Square & Value & Prob $>$ F & \\
\hline Model & 239.38 & 8 & 29.92 & 187.04 & 0.0006 & significant \\
\hline A-A & 85.94 & 1 & 85.94 & 537.18 & 0.0002 & \\
\hline B-B & 0.45 & 1 & 0.45 & 2.79 & 0.1934 & \\
\hline $\mathrm{C}-\mathrm{C}$ & 0.74 & 1 & 0.74 & 4.61 & 0.1209 & \\
\hline $\mathrm{AB}$ & 13.29 & 1 & 13.29 & 83.05 & 0.0028 & \\
\hline $\mathrm{AC}$ & 6.13 & 1 & 6.13 & 38.29 & 0.0085 & \\
\hline BC & 31.81 & 1 & 31.81 & 198.84 & 0.0008 & \\
\hline A2 & 92.14 & 1 & 92.14 & 575.97 & 0.0002 & \\
\hline B2 & 54.50 & 1 & 54.50 & 340.66 & 0.0003 & \\
\hline $\mathrm{C} 2$ & 0.000 & 0 & & & & \\
\hline Residual & 0.48 & 3 & 0.16 & 187.04 & & \\
\hline Cor Total & 239.86 & 11 & & & & \\
\hline
\end{tabular}


nificance of each of the coefficients and is indicative of interaction strength of each independent variable. $\mathrm{P}$-value less than 0.05 indicate that the model terms are significant. In this experiment, the Model F-value of 285.87 implied that the model is significant in enhancing enzyme production In this case A (Tannic acid ), G (Dummy), H (Dummy) and J (Dummy) gave significant terms and $\mathrm{B}, \mathrm{C}, \mathrm{D}, \mathrm{K}$ and $\mathrm{E}$ gave negative significant terms.

\section{Optimization of significant variables by Response surface methodology (RSM)}

Tannic acid was found to be significant by PBD was optimized by RSM using Box-Behnken design for tannase production. The response values in terms of tannase activity and the matrix design were represented in Table 4.

The results obtained by Box-Behnken were analyzed by Analysis of variance (ANOVA) with a model F-value of 187.04 indicating that the model was significant (Table 5). Values of Prob $>\mathrm{F}$ less than 0.05 indicate that the model terms are significant. In the present model $\mathrm{A}, \mathrm{AB}, \mathrm{BC}, \mathrm{AC}, \mathrm{A}^{2}, \mathrm{~B}^{2}$ are significant model terms. The Model F-value of 187.04 implies the model is significant. There is only a $0.06 \%$ chance that an F-value this large could occur due to noise. The Values of "Prob > F" less than 0.0500 indicate model terms are significant.This fit of the model was checked with the coefficient of determination $\mathrm{R}^{2}$, which was calculated to be 0.9680 . The determination coefficient $\left(R^{2}\right)$ of the model was 0.9980 indicating that $99.80 \%$ of variability in the response could be accounted by the model.

The ANOVA gave the following regression equation:

$$
\begin{aligned}
& \mathrm{R} 1=+19.97-3.28^{*} \mathrm{~A}-0.24^{*} \mathrm{~B}+0.30^{*} \mathrm{C}-1.82^{*} \\
& \quad \mathrm{AB}-1.24^{*} \mathrm{AC}+2.82^{*} \mathrm{BC}-6.79^{*} \mathrm{~A}^{2}-5.22^{*}+0.000^{*} \mathrm{C}^{2}
\end{aligned}
$$

Where $\mathrm{R} 1$ is the tannase activity; $\mathrm{A}$ is tannic acid; $\mathrm{B}$ is $\mathrm{KCl}$; $\mathrm{C}$ is $\mathrm{KH}_{2} \mathrm{PO}_{4}$ and the interactions $\mathrm{AB}, \mathrm{BC}, \mathrm{AC}, \mathrm{A}^{2}, \mathrm{~B}^{2}$ are significant.

\section{D Surface Plots}

The three-dimensional response surface curves were plotted to study the interaction among different physicochemical factors used and to find out the optimum concentration of each factor for maximum tannase production.

For the construction of 3D plots, effect of two variables was considered while the other variable was held at zero. These plots were helpful in understanding both the individual and the interaction effects of the two factors. For the construction of 3Dplots, effect of two variables was considered while the other variable was held at zero. From the 3D plots, it was clear that the tannase activity significantly increased with increase in the con- centration of tannic acid (A) reaching to its maximum at $18.12 \mathrm{U} / \mathrm{ml} / \mathrm{min}$, where as the enzyme activity gradually increased with increase $\mathrm{KCl}(\mathrm{B})$ concentration and then declined (Figure 2a).Significant interactions were also present between $\mathrm{KCl}(\mathrm{B})$ and $\mathrm{KH}_{2} \mathrm{PO}_{4}(\mathrm{C})$ with a low p-value (0.0008) and between $\mathrm{KH}_{2} \mathrm{PO}_{4}(\mathrm{C})$ and tannic $\operatorname{acid}(\mathrm{A})$ with a low p-value (0.0085) (Figure 2b and 2c).

Validation of the Model: Validation of the response surface model was confirmed by using optimum conditions obtained by the model. The experimental values were very close to the predicted values and hence it was concluded that the model was successfully validated.

\section{CONCLUSION}

The response surface methodology was applicable for the production of tannase from Streptomyces sp. AT13. In the present study,optimum conditions for tannase production by Streptomyces $s p$. AT13 was done using Plackett-Burmen design followed by Response surface methodology using Box-Behnken design. From among 6 fermentative variables that were studied, 5 significant variables were picked up by PBD. Among 5 variables from PBD, 3 were further optimized by Box-Behnken design. Analysis of variance (ANOVA) showed the significance of the model and the validity of the model was confirmed by the verification experiments. P-value less than 0.05 indicate that the model terms are significant. The optimum values of parameters obtained through RSM were $1 \%$ tannic acid, $0.5 \% \mathrm{KCl}$ and $0.1 \% \mathrm{KH}_{2} \mathrm{PO}_{4}$ to achieve maximum tannase production.

\section{ACKNOWLEDGMENTS}

The Authors are thankful to the head of Department of Biotechnology and Microbiology, KSV University for providing all the laboratory facilities. The authors are also thankful to Biogene department of Gujarat State Biotechnology Mission (GSBTM), Gandhinagar, Gujarat, India for bacterial strain identification.

\section{COMPLIANCE WITH ETHICAL STANDARDS}

Conflict of Interests: There are no conflicts of interest.

\section{REFERENCES}

Barthomeuf, C., Regerat, F., Pourrat, H. (1994). Production, purification and characterization of a tannase from Aspergillus niger LCF 8. J. Ferment. Bioeng. 3: 320-323.

Bate-Smith, E.C. and Swain, T. (1962). Flavonoid compounds., In: Comparative biochemistry. Academic Press, Pp 755-809 (Eds) Mason and A.M. Florkin. New York. 
Beena P.S., Soorej, M.B., Elyas, K.K., Sarita, G.B., Chandrasekaran, M. (2010). Acidophilic tannase from marine Aspergillus awamori BTMFW032. J Microbiol Biotechnol., 20:1403-1414.

Bhat, T.K., Singh, B. and Sharma, O.P. (1998). Microbial degradation of tannins-a current perspective. Biodegradation, 9:343-357.

Dilipkumar, M., Rajasimman, M., Rajamohan, N. (2011). Application of statistical design for the production of inulinase by Streptomyces $s p$. using press mud. Front Chem Sci Eng.; 5(4):463-470. doi: 10.1007/s11705-011-1112-1.

Haslam, E. (1989). In Plant Polyphenols Plant Polyphenols: Vegetable Tannins Revisited. Cambridge: Cambridge University Press. Cambridge, Pp 230. Cambridge.

Lekha, P.K., Lonsane, B.K. (1997). Production and application of tannin acyl hydrolase: state of the art. Adv Appl Microbiol 44:215-260.

Mannan S., Fakhrul-Razi, A., Alam, M.Z. (2007). Optimization of process parameters for the bioconversion of activated sludge by Penicillium corylophilum, using response surface methodology. J Environ Sci. (China):19(1):23-8.

Mcleod, M.N. (1974). Plant tannins - their role in forage quality. Nutrition Abstracts and Reviews 44:803-815.
Mohan, S. K. (2014). Optimization of tannase production from agro industrial wastes- kinetics and modelling. From: Ph. D. Thesis. Department of Chemical Engineering, Annamalai University, Annamalainagar, Tamilnadu, India.

Pan, C.M., Fan, Y.T., Xing, Y., Hou, H.W., Zhang, M.L. (2008). Statistical optimization of process parameters on biohydrogen production from glucose by Clostridium $s p$. Fanp2. Bioresour Technol.; 99(8):3146-54.

Rana, N. K. and Bhat, T. K. (2005). Effect of Fermentation System on the Production And Properties of Tannase from Aspergillus niger van Tighem MTCC 2425. Journal of Applied Microbiology. 51: 203-212.

Rodríguez, H., De las Rivas, B., Gómez-Cordovés, C., Munoz, R. (2008). Degradation of tannic acid by cell-free extracts of Lactobacillus plantarum. Food Chem.107:664-670.

Sharma, S., Bhat, T.K., Dawra, R.K. (2000). A Spectrophotometric Method for Assay of Tannase Using Rhodonine. Anal. Biochem. 278: 85-89.

Van de Lagemaat, J. and Pyle, D.L. (2006). Tannase. In: Enzyme Technology. Pp 380-397 (Eds) A. Pandey, A.C. Webb, C.R. Soccol and C. Larroche,1st Edn., Springer, New York. 